\title{
THE INHERITANCE OF PHEROMONE PRODUCTION IN THE SULPHUR BUTTERFLIES COLIAS EURYTHEME AND C. PHILODICE
}

\author{
JOHN W. GRULA* and ORLEY R. TAYLOR, Jr. \\ Department of Systematics and Ecology, University of Kansas, Lawrence, Kansas 66045, U.S.A. \\ Received 20.xi.78
}

\begin{abstract}
Summary
The inheritance of male pheromone production in the sulphur butterflies Colias eurytheme and $C$. philodice was determined by gas chromatographic analyses of wing extracts from various genotypes derived from interspecific crosses. A wing ultraviolet-reflectance pattern (found only in $C$. eurytheme males) which is controlled by an X-linked gene served as a marker for determining the relative influence of this chromosome $v$. the autosomes on pheromone production. The data indicate that production of the most important $C$. philodice wing compounds, three different $n$-hexyl esters, is controlled by one or more autosomal genes that are at least codominant. The X-chromosome carries most of the genes or the gene controlling production of the most important C. eurytheme compound, 13-methyl heptacosane. Expression of this compound in hybrids displays a codominant pattern. Because the wing ultraviolet-reflectance pattern of male $C$. eurytheme is an important courtship signal, it appears that all of the genes controlling the male courtship signals of this species are inherited as a co-adapted gene complex on the $\mathrm{X}$-chromosome. The evolution of $\mathrm{X}$-chromosomal control of both the visual (wing UV-reflectance pattern) and olfactory (13-methyl heptacosane) components of the courtship communication system of $C$. eurytheme is discussed and compared to the mode of inheritance of other communication systems.
\end{abstract}

\section{INTRODUCTION}

The closely related sulphur butterflies, Colias eurytheme and $C$. philodice, occur together over most of North America. Long thought to interbreed at random (Hovanitz, 1944), it has recently been demonstrated that these species are sexually isolated under most natural conditions (Taylor, 1972). Behavioural and chemical evidence indicate that the isolation between $C$. eurytheme and $C$. philodice is based upon female response to species-specific visual and pheromonal signals (Grula, 1978; Silberglied and Taylor, 1978). Because $C$. eurytheme and $C$. philodice retain a substantial amount of genetic compatibility (Gerould, 1943; Ae, 1959) and the nature of their courtship communication systems is so well known, these species offer a rare opportunity to analyse genetically the communication traits which are maintaining their isolation. Consequently, studies have been undertaken to determine the mode of inheritance of the male visual and pheromonal signals and female response to these signals. Expression of the only important visual cue, a wing ultraviolet reflection pattern found only in $C$. eurytheme males, is controlled by a recessive allele $\left(X^{u}\right)$ located on the X-chromosome (Silberglied and Taylor, 1973). Ultraviolet-reflecting wings appear in those $\mathrm{F}_{2}$

* Present address: Kerckhoff Marine Laboratory, 101 Dahlia, Corona del Mar, California 92625 , USA. 
and backcross males with two eurytheme X-chromosomes (males being the homogametic sex in Lepidoptera). The wings of $C$. philodice males $\left(X^{U} X^{U}\right)$ and $\mathrm{F}_{1}$ males $\left(X^{U} X^{u}\right)$ absorb UV light. The trait is sex-limited and not expressed in females of either species.

Recent identification of several compounds making up the speciesspecific pheromone systems (Grula, 1978) has also made possible a genetic analysis of the chemical signals important in courtship. Using the UVreflecting trait as an X-chromosome marker, $\mathrm{X}$-chromosomal and/or autosomal locations have been assigned to the genes controlling pheromone production. The results also permit dominance relationships to be established.

\section{Materials AND methods}

\section{(i) Pheromone identification}

Gas chromatography (GC) and mass spectrometry were employed to identify the male aphrodisiac pheromones of each species. The compounds were extracted by washing the wings of 50-100 individuals with ether. Wild males collected in the vicinity of Lawrence, Kansas, were used for chemical structure determination of the major wing compounds. For a full description of the methods of analysis and data concerning the chemical identity of each compound, see Grula (1978).

The biological activities of the wing compounds were determined with three different assays. These included electroantennogram recordings obtained by methods similar to those of Roelofs and Comeau (1971), a behavioral assay developed by Rutowski (1977), and a speciesrecognition experiment conducted with large numbers of females and males chemically modified to resemble the other species. See Grula (1978) for the assay results.

\section{(ii) Genetic analysis of pheromone production}

Most of the individuals used for genetic analysis of pheromone production were reared in the laboratory on an artificial diet using methods similar to those of Shorey and Hale (1965). Rearing the insects on artificial diet affects the production of some pheromonal compounds. The nature of these alterations are explained in the Results. Pheromone production data were obtained from wild $F_{1}$ males to partly circumvent the difficulties presented by the dietary influence on pheromone synthesis.

All genotypes were derived from naturally occurring matings obtained in an indoor flight cage. The wing compounds of $F_{1}, F_{2}$ and several classes of backcross males were extracted and analysed by GC using the same methods employed to establish the pheromone phenotypes of the parent species. In most cases at least 20 individuals of a given genotype were used to make an extraction. The two types of $F_{2}$ males were an exception to this. Twelve ultraviolet-reflecting $\mathrm{F}_{2}$ males $\left(X^{u} X^{u}\right)$ and six ultravioletabsorbing $\mathrm{F}_{2}$ males $\left(X^{U} X^{u}\right)$ were all that could be obtained to determine the pheromone phenotypes of these different $\mathrm{X}$-chromosome genotypes. As the results show, however, these numbers were sufficient to obtain the required information.

Comparative GC column-retention time data were used to verify the identity of the wing compounds produced by the various genotypes. There 
were no indications that any of the hybrids produce significant amounts of any novel compounds. GC chromatogram peak areas were measured to quantify pheromone production.

\section{Results}

Typical GC chromatograms of wing extracts from wild (field-collected) and laboratory-reared Colias philodice and C. eurytheme males are shown in figs. 1 and 2. The seven major $C$. philodice wing compounds consist of a trio of esters and a series of straight-chain hydrocarbons with odd carbon numbers $\left(\mathrm{C}_{23}\right.$ through $\left.\mathrm{C}_{29}\right)$. Mass spectral analyses of pure samples have shown that the esters are $n$-hexyl myristate (HM), n-hexyl palmitate (HP), and n-hexyl stearate (HS). The hydrocarbons include n-tricosane (T), n-pentacosane $(\mathrm{P})$, n-heptacosane $(\mathrm{H})$, and n-nonocosane $(\mathrm{N})$. C. eurytheme produces the same series of straight-chain hydrocarbons, but the three esters found in $C$. philodice are absent in this species. However, C. eurytheme synthesises a large amount of a branched hydrocarbon, 13-methyl hepta cosane, which $C$. philodice produces in much smaller quantities.
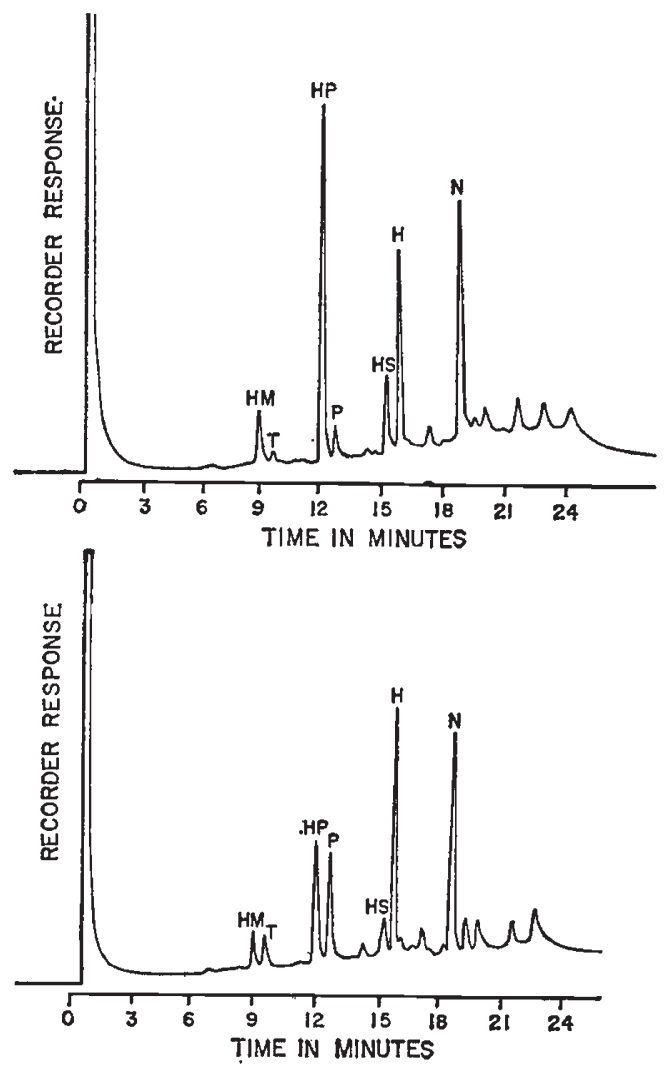

FIG. 1.-Gas chromatograms of ether extracts from wings of Colias philodice males. Top, field-collected males; bottom, laboratory-reared males. $H M=n$-hexyl myristate, $\mathrm{T}=\mathrm{n}$-tricosane, $\mathrm{HP}=\mathrm{n}$-hexyl palmitate, $\mathrm{P}=\mathrm{n}$-pentacosane, $\mathrm{HS}=\mathrm{n}$-hexyl stearate, $\mathrm{H}=\mathrm{n}$-heptacosane, $\mathrm{N}=\mathrm{n}$-nonacosane. 

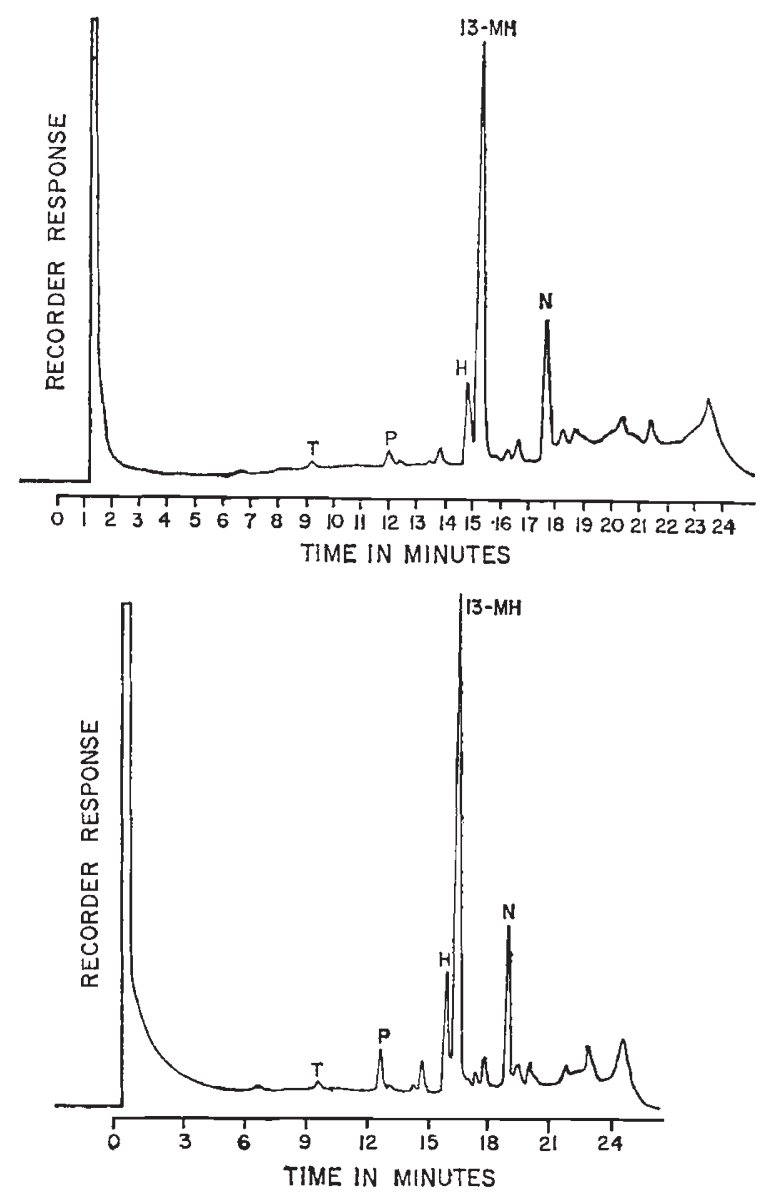

FIG. 2.-Gas chromatograms of ether extracts from wings of Colias eurytheme males. Top, field-collected males; bottom, laboratory-reared males. $T=n$-tricosane, $P=n$ pentacosane, $\mathrm{H}=\mathrm{n}$-heptacosane, $13-\mathrm{MH}=13$-methyl heptacosane, $\mathrm{N}=\mathrm{n}$-nonacosane.

\section{(i) Inheritance of ester production in Colias philodice}

C. philodice males which are raised on artificial diet produce substantially smaller amounts of the three esters unique to this species than do wild males (compare two chromatograms in fig. 1). In contrast, pheromone production in $C$. eurytheme shows no dietary influence and chromatograms obtained from wild and laboratory-reared males are essentially identical (fig. 2). Hydrocarbon production in C. philodice is also unaffected by diet. Because ester production is reduced in laboratory-reared specimens, the mode of inheritance of these compounds was difficult to establish clearly. Analysis of field-collected $F_{1}$ males provided a partial solution to this problem. These individuals are easily distinguished by their wing coloration in the visible and ultraviolet parts of the spectrum (Silberglied and Taylor, 1973) The level of ester production by wild $F_{1}$ males indicates that the allele(s) responsible are dominant (fig. 3). Except for producing 13-methyl heptacosane in an amount intermediate between the parent species, the pheromone 


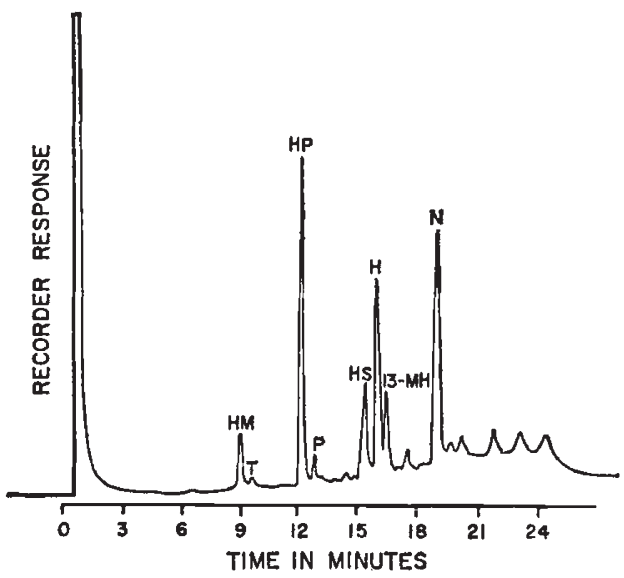

Fig. 3.-Gas chromatogram of ether extract from wings of field-collected $F_{1}$ males.
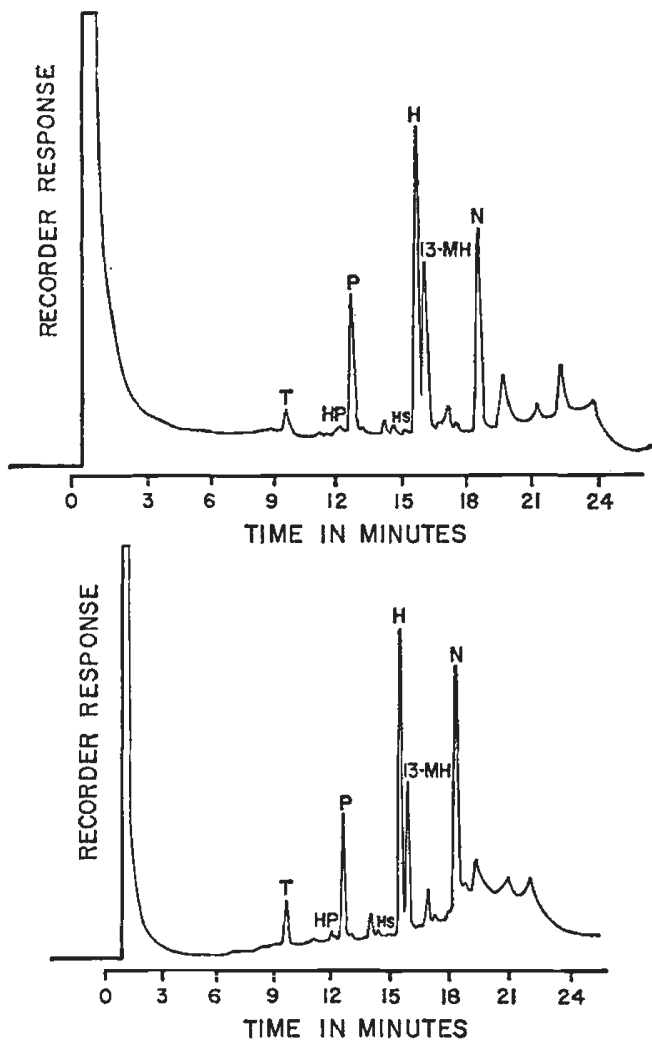

Fig. 4.- Gas chromatograms of ether extracts from wings of laboratory-reared $F_{1}$ males. Top, Type $1 F_{1}$ (philodice female $\times$ eurytheme male); bottom, Type $2 F_{1}$ (eurytheme female $\times$ philodice male).

$42 / 3-F$ 
phenotype of wild $\mathrm{F}_{1}$ males is essentially identical to that of wild $C$. philodice males (fig. 1). This result concurs with field mating data which indicate that $\mathrm{F}_{1}$ and $C$. philodice males are treated similarly by females of both species (Taylor, 1972).

In contrast to data obtained from field-collected $F_{1}$ hybrids, the data concerning ester production derived from the laboratory-reared genotypes suggest that the allele(s) controlling the production of these compounds is (are) codominant. Males from both interspecific crosses produce the esters in amounts intermediate between $C$. philodice and $C$. eurytheme (fig. 4). However, it is also possible to interpret the reduced levels of ester synthesis as a dosage phenomenon which becomes apparent only when the ester precursors are limited in the diet.

The pattern of ester production among the backcross and $F_{2}$ genotypes indicates that the gene(s) regulating their production have autosomal locations. Those genotypes which have 50 per cent or more philodice autosomes $\left(\mathrm{F}_{1}, \mathrm{~F}_{2}\right.$ and Type 4 backcross males) produce the compounds in detectable amounts (figs. 4, 6 and 7). Ester production is absent or barely detectable in Types 1 (eurytheme $ᄋ \times \mathrm{F}_{1}$ ठ) and 3 (Type $1 \mathrm{~F}_{1}$ \% $\times$ eurytheme $\left.{ }^{\top}\right)$ backcross males whose autosomes are on average only onequarter philodice (fig. 5). There is little difference in ester synthesis between

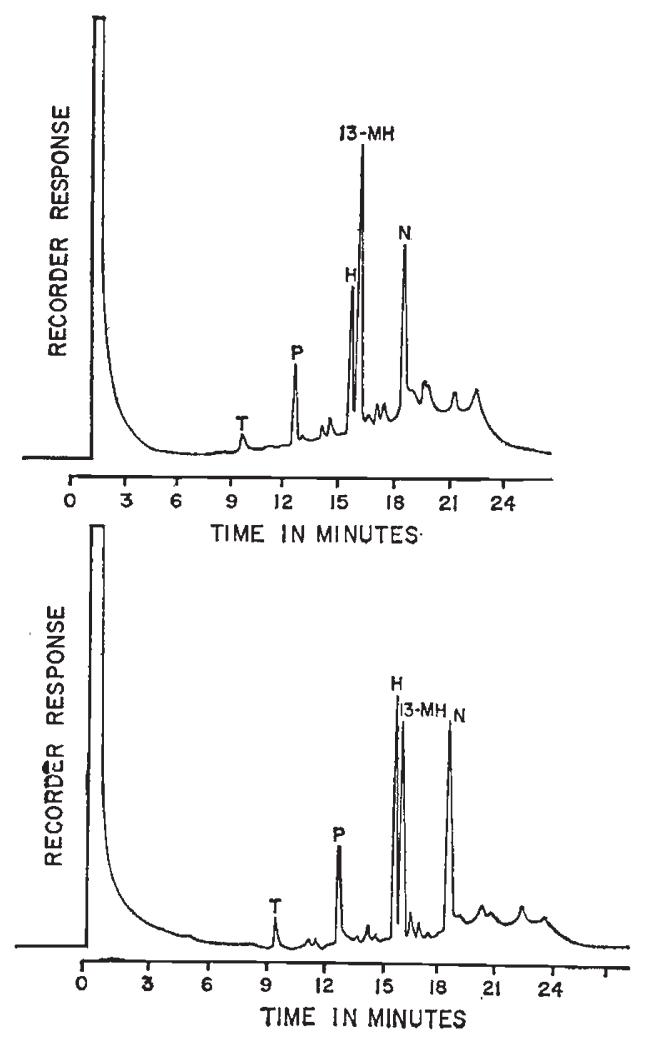

FIG. 5.-Gas chromatograms of ether extracts from wings of laboratory-reared Type 1 backcross (eurytheme female $\times F_{1}$ male) males. Top, UV-reflecting $\left(X^{u} X^{u}\right)$ males; bottom, UV-absorbing $\left(X v X^{u}\right)$ males. 
the two $\mathrm{X}$-chromosome genotypes $\left(X^{u} X^{u}\right.$ and $\left.X^{U} X^{u}\right)$ which segregate in the Type 1 backcross (fig. 5). This would not be expected if the inheritance of these compounds were X-chromosomal, but it does agree with autosomal inheritance. The strongest evidence for an autosomal location of the esterproducing gene(s) is provided by the $\mathrm{F}_{2}$ individuals. If these genes are located on the X-chromosome, then ester production should be absent in the ultraviolet-reflecting males derived from this cross (which have two eurytheme X-chromosomes- $\left.X^{u} X^{u}\right)$. However, this genotype produces similar amounts of the esters to the ultraviolet-absorbing males from the same cross $\left(X^{U} X^{u}\right)$ and $\mathrm{F}_{1}$ males (see figs. 4 and 7 ). This accords with their autosomal make-up, which is on average one-half philodice (as it is in the UV-absorbing $F_{2}$ and $F_{1}$ males).

\section{(ii) Inheritance of hydrocarbon production}

The hydrocarbons produced by both species are not affected by diet and consequently the inheritance of their production is more easily resolved. Males of both species produce similar, small quantities of n-tricosane $\left(\mathrm{C}_{\mathbf{2 3}}\right)$ and n-pentacosane $\left(\mathrm{C}_{25}\right)$ and larger amounts of n-nonocosame $\left(\mathrm{C}_{29}\right.$, see figs. 1 and 2). The major difference is in the relative amounts of the straight-chain hydrocarbon, $n$-heptacosane $\left(\mathrm{C}_{27}\right)$, and the branched hydrocarbon, 13-methyl heptacosane $\left(\mathrm{C}_{28}\right)$, found in each species. C. eurytheme produces much larger quantities of 13 -methyl heptacosane than n-heptacosane (fig. 2). The situation is reversed in C. philodice (fig. 1). Therefore, genetic analysis is confined to these two compounds.

The ratio of n-heptacosane to 13-methyl heptacosane synthesized by the various genotypes is tabulated in table 1 . Wild $\mathbf{F}_{\mathbf{1}}$ hybrids and both types of laboratory-reared $F_{1}$ hybrids produce the straight and branched hydrocarbons in ratios intermediate between the parent species, although n-heptacosane is still the predominant compound (see figs. 3 and 4). Field-collected and Type $2 \mathrm{~F}_{1}$ hybrids (eurytheme o $\times$ philodice $\widehat{\jmath}$ ) reared in the laboratory have an almost identical expression of the two compounds (72:28 and $73: 27$ production ratios of $n$-heptacosane to 13-methyl heptacosane, respectively). Type $1 \mathrm{~F}_{1}$ hybrids (philodice $q \times$ eurytheme $\sigma^{\top}$ ) reared in the laboratory are similar but exhibit a slight paternal effect $(66: 34)$. The chemical identity between field-collected and Type $2 \mathrm{~F}_{1}$ hybrids in hydrocarbon content corresponds to the fact that the Type 2 interspecific cross (eurytheme $+\times$ philodice $\delta$ ) occurs more often in the field (Taylor, 1972). Therefore both pheromone production and field data indicate that most wild $F_{1}$ males are from the second type of interspecific cross.

The intermediate ratios of n-heptacosane to 13-methyl heptacosane production found in $\mathrm{F}_{1}$ hybrids is explicable by either autosomal or $\mathrm{X}$ chromosomal inheritance (males being the homogametic sex in Lepidoptera). The nearly complete control by the $\mathrm{X}$-chromosome on the production of these compounds is revealed when comparisons are made between the two $\mathrm{X}$-chromosome genotypes which segregate in crosses involving an $\mathrm{F}_{1}$ male parent. These include the Type 1 backcross (eurytheme $q \times \mathrm{F}_{1} \delta$ ) and the $\mathrm{F}_{2}$ cross (Type $1 \mathrm{~F}_{1}+\times \mathrm{F}_{1} \sigma^{\top}$ ). In these cases, wing UV-reflecting or UV-absorbing characteristics were used to detect homozygous $\left(X^{u} X^{u}\right.$ and UV-reflecting) and heterozygous ( $X^{U} X^{u}$ and UV-absorbing) $\mathrm{X}$-chromosome 
genotypes. Separate analysis of these two genotypes allows the effect of a difference in one $\mathrm{X}$-chromosome on hydrocarbon production to be detected, since the autosomal compositions are the same.

Type 1 backcross males that are UV-reflecting $\left(X^{u} X^{u}\right)$ produce $\mathrm{n}$ heptacosane and 13-methyl heptacosane in a ratio similar to eurytheme (32: 68 and $18: 82$, respectively, v. $96: 4$ for philodice-see figs. 1, 2 and 5 and table 1). However, in UV-absorbing males from the same cross $\left(X^{U} X^{u}\right)$, n-heptacosane is the predominant compound (56:44) even though the autosomes of these individuals are on average 75 per cent eurytheme (fig. 5 and table 1).

A large difference in hydrocarbon production ratio is also seen between the two $\mathrm{X}$-chromosome genotypes segregating in the $\mathrm{F}_{2}$ cross. Even with an autosomal background on average one-half philodice, UV-reflecting $\mathrm{F}_{2}$ males $\left(X^{u} X^{u}\right)$ produce n-heptacosane and 13-methyl heptacosane in a ratio much more like that of eurytheme (35:65, see also fig. 7). Conversely, $\mathrm{UV}$-absorbing individuals from the same cross $\left(X^{U} X^{u}\right)$ exhibit a production ratio resembling that of $F_{1}$ males and much more similar to philodice (78:22-fig. 7).

Finally, Type 3 backcross (Type $1 F_{1}$ ox eurytheme đ̊) males which
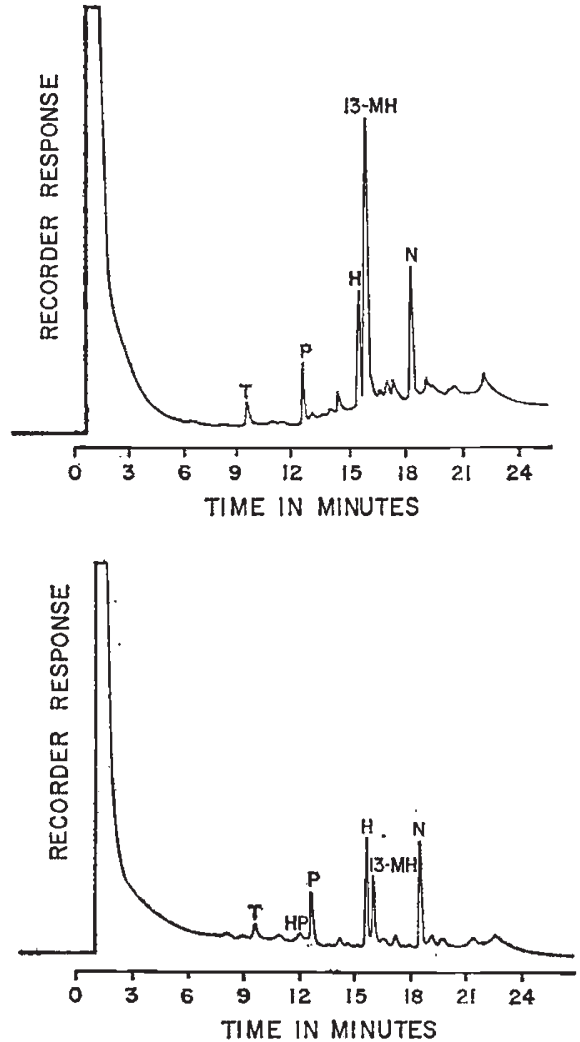

FIG. 6.-Gas chromatograms of ether extracts from wings of laboratory-reared backcross males. Top, Type 3 backcross (Type $1 \mathrm{~F}_{1}$ female $\times$ eurytheme male) males; bottom, Type 4 backcross (Type $1 \mathrm{~F}_{1}$ female $\times$ philodice male) males. 


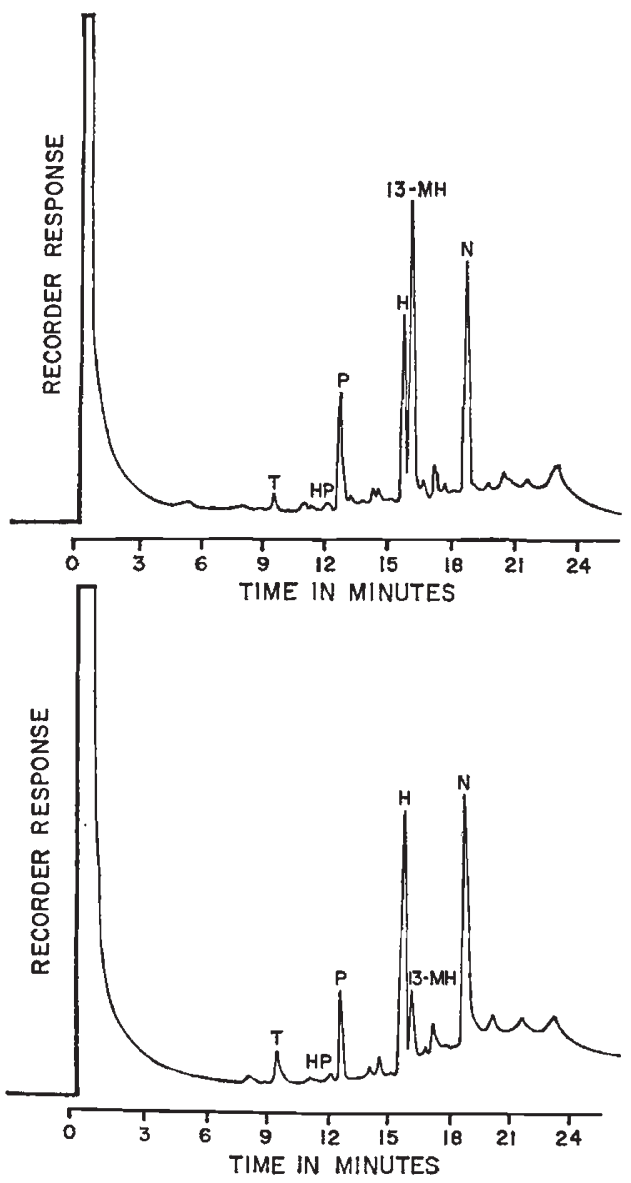

FIG. 7.-Gas chromatograms of ether extracts from wings of laboratory-reared $\mathbf{F}_{2}$ (Type 1 $F_{1}$ female $\times F_{1}$ male) males. Top, UV-reflecting $\left(X^{u} X^{u}\right)$ males; bottom, UV-absorbing $\left(X^{U} X^{u}\right)$ males.

are all UV-reflecting $\left(X^{u} X^{u}\right)$ and autosomally on average 75 per cent eurytheme produce n-heptacosane and 13-methyl heptacosane in a ratio that reflects these facts (24:76-see also fig. 6). The production ratio of this genotype closely resembles that of the UV-reflecting Type 1 backcross males (32: 68 and fig. 5), with which they share genetic identity by way of a different cross. The ratio of n-heptacosane to 13-methyl heptacosane production found in Type 4 backcross (Type $1 \mathrm{~F}_{1}$ o $\times$ philodice $\sigma^{\star}$ ) males64 : 36-also lends strong support for a potent X-chromosomal influence on hydrocarbon synthesis (fig. 6). However, the results obtained from this genotype do not clarify the effect of autosomal background. Because the autosomes of these individuals are on average 75 per cent philodice (while the $\mathrm{X}$-chromosomes are heterozygous), a ratio more similar to philodice (96:4) would be expected.

The large $\mathrm{X}$-chromosome effect on hydrocarbon production in $C$. eurytheme and $C$. philodice gains more significance in light of the fact that this chromosome is difficult to distinguish from the autosomes, of which 
TABLE 1

The effect of X-chromosome inheritance on pheromone production in Colias eurytheme and $\mathrm{C}$. philodice as indicated" by the ratio of $n$-heptacosane to 13-methyl heptacosane residing on the wings of various male genotypes

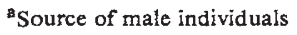

Colias eurytheme (E)

Colias philodice (P)

Field collected $\mathbf{F}_{1}$

Type $1 \mathrm{~F}_{1}(\mathbf{P}$ o $\times \mathbf{E}$ o $)$

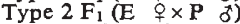

Type $1 \mathrm{BC}\left(\mathrm{E}+{ }_{\uparrow} \times \mathrm{F}_{1}\right.$ ठ)

Type 3 BC (Type $1 F_{1} \quad q \times E \quad$ ot)

Type 4 BC (Type $1 \mathrm{~F}_{1} q \times \mathrm{P}$ ठै)

Type $1 F_{2}$ (Type $\left.1 F_{1} q \times F_{1} \sigma^{\prime}\right)$

\begin{tabular}{|c|c|c|c|c|}
\hline \multicolumn{2}{|c|}{ Genotype } & \multicolumn{2}{|c|}{ Wing uItraviolet } & \multirow{2}{*}{$\begin{array}{c}\text { eRatio of } \\
\text { n-heptacosane to } \\
\text { 13-methyl heptacosane }\end{array}$} \\
\hline Autosomes & bX-chromosomes & 'Phenotype & ${ }^{d}$ Genotype & \\
\hline 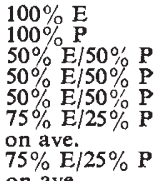 & $\begin{array}{l}\text { EE } \\
\text { PP } \\
\text { EP } \\
\text { EP } \\
\text { EP } \\
\text { EE } \\
\text { EP } \\
\text { EE }\end{array}$ & $\begin{array}{l}(+) \\
(-) \\
(-) \\
(-) \\
(-) \\
(+) \\
(-) \\
(+)\end{array}$ & $\begin{array}{l}X u X u \\
X^{u} X^{u} \\
X U X u \\
X U X u \\
X U X X^{u} \\
X U X^{u} \\
X u X u \\
X^{U} X^{u} \\
X^{u} X^{u}\end{array}$ & $\begin{array}{l}18: 82 \\
96: 4 \\
72: 28 \\
66: 34 \\
73: 27 \\
32: 68 \\
56: 44 \\
24: 76\end{array}$ \\
\hline $\begin{array}{l}75 \% \mathrm{P} / 25 \% \mathrm{E} \\
\text { on ave. }\end{array}$ & EP & $(-)$ & $X^{U} X^{u}$ & $64: 36$ \\
\hline $\begin{array}{l}50 \% \mathrm{E} / 50 \% \mathrm{P} \\
\text { on ave. }\end{array}$ & $\begin{array}{l}\text { EE } \\
\text { EP }\end{array}$ & $\stackrel{(+)}{(-)}$ & $\begin{array}{l}X u X u \\
X U X u\end{array}$ & $\begin{array}{l}35: 65 \\
78: 22\end{array}$ \\
\hline
\end{tabular}

a All individuals were laboratory-reared on artificial diet unless otherwise indicated. In this study no individuals were obtained from the Type $2 \mathrm{BC}\left(\mathbf{P} \circ \times \mathrm{F}_{1} \delta\right)$ or any backcrosses and $\mathrm{F}_{8}$ crosses involving Type $2 \mathrm{~F}_{1}$ females (Type 5 and $6 \mathrm{BC}$ and Type $2 \mathrm{~F}_{2}$ ). The number designations for the crosses which appear here match those used in other papers.

b Males are the homogametic sex in all Lepidoptera investigated, including Colias (Robinson, 1971).

c $(+)=$ Wings reflect ultraviolet light. $(-)=$ Wings absorb ultraviolet light.

d $(+)=$ Wings reflect ultraviolet light. $(-)=$ Wings absorb ultraviolet light.

The ratio of these compounds produced by the different genotypes was determined by measuring gas-liquid chromatogram peak areas.

there are 30 small and very similar pairs (Maeki and Remington, 1960). It follows that the X-chromosomes constitute approximately $1 / 30$ of the genome in male Colias. While a partial autosomal influence on hydrocarbon production is evident, all the data taken together indicate that the Xchromosome of $C$. eurytheme and $C$. philodice exerts a highly disproportionate influence on the amounts of n-hept acosane and 13-methyl heptacosane residing on the wings of males. Most of the loci (or possibly, the locus) controlling the relative amounts of these compounds must be X-linked. Intermediate expression of 13-methyl heptacosane in all of the X-chromosome heterozygotes also indicates that the loci are codominant.

\section{Discussion}

From the results of this study and that of Silberglied and Taylor (1973), it is evident that the $\mathrm{X}$-chromosome carries major genes controlling expression of the male courtship signals of $G$. eurytheme. These signals include the only critical visual cue-a wing ultraviolet-reflection patternand the most important pheromone component, 13-methyl heptacosane. On the other hand, both autosomal and X-chromosomal loci regulate male pheromone production in $C$. philodice (females of this species use only chemical cues for selecting conspecific mates, Silberglied and Taylor, 1978). The data indicate that one or more autosomal gene(s) control production of the esters unique to $C$. philodice-n-hexyl myristate, n-hexyl palmitate, and n-hexyl stearate-while the X-chromosome is the site of most of the genes regulating synthesis of probably the most important hydrocarbon component of the pheromone system, n-heptacosane.

There have been few studies of the genetic basis of pheromone production. Among those that have been reported, direct comparisons are difficult because the investigators used behavioural responses as the criteria for evaluating the nature of the pheromones produced by hybrid genotypes.

Working with hybrids between three species of bark beetles in the genus Ips, Lanier (1970) found that pheromone production and pheromone 
response are influenced to approximately the same extent by both parental genomes, suggesting that codominant autosomal loci control the chemical communication system. Conversely, Grant et al. (1972) discovered a disproportionate maternal effect on both sex pheromone production and pheromone response in one type of $F_{1}$ hybrid between two species of tussock moths. However, the limited genetic data prohibited drawing any firm conclusions about the characteristics of the loci involved. Furthermore, in a study of several species of coniferophagous moths in the genus Choristoneura, Sanders et al. (1977) obtained some evidence for control of pheromone production by both X-chromosomal and autosomal loci in two of the species. Their results also indicated that the mechanisms regulating the production of an aldehydic compound are dominant to those regulating the production of a homologous acetate. Again, the absence of chemical analyses and the limited extent of the genetic data made it difficult to draw any definite conclusions. However, a more detailed description of the genes controlling the multiple sex pheromone system of Drosophila melanogaster has been achieved by Averhoff and Richardson (1976). Concerned primarily with intraspecific pheromone variation, these investigators found that loci for male and female courtship pheromones are dispersed throughout the genome. Genes involved in the production of a volatile female pheromone were localised to the $\mathrm{X}$ and/or fourth chromosomes. Second and/or third chromosomal sites were resolved for the genes controlling the production of a volatile male pheromone.

The contrast between the results reported here (which strongly implicate tight linkage among the loci controlling the courtship signals of at least one species, C. eurytheme) and those of Averhoff and Richardson (1976) raises the interesting possibility that insect communication systems have both variable and invariable components and that different sets of genes with different modes of inheritance give rise to this dichotomy. Behavioral evidence that intraspecific pheromone variation is great enough to make possible individual recognition exists for several species (Barrows et al., 1975; Leonard and Ehrman, 1976). The results presented here support conclusions reached by theoretical analyses (Alexander, 1962; O'Donald, 1962) that species-specific (and presumably invariable) features of communication systems should be inherited as blocks of co-adapted gene complexes or supergenes. Conversely, the results of Averhoff and Richardson (1976) indicate that the loci affecting intraspecific variation in these systems are distributed throughout the genome and inherited independently. This is probably to be expected as independent assortment between these loci would, of course, produce a larger array of genotypes. Because there is evidence that negatively assortative mate-selection by female Drosophila is based upon variation in pheromonal signals (Ehrman, 1970), this would promote outbreeding during population bottlenecks as pointed out by Averhoff and Richardson (1976).

Finally, although investigations to date concerning the genetic basis of pheromone production have not provided clear parallels to the results of this study, it is noteworthy that the acoustic courtship signals of hybridizable yet reproductively isolated species of Drosophila (Ewing, 1969) and field crickets (Bentley, 1971; Hoy, et al., 1977) have been demonstrated to be influenced strongly by X-chromosomal loci. An X-chromosomal location for the genetic structure underlying a communication system may confer 
several advantages. Successful courtship and prevention of hybridization usually requires the transmission and reception of a very specific set of signals. The construction and maintenance of such highly co-adapted systems probably occurs only when selection pressure is great. As pointed out by Ewing (1969), X-linked loci experience more intense selection than autosomal loci because of their hemizygotic condition in the heterogenetic sex. As a result, fixation of adaptive or elimination of maladaptive allelic combinations is more rapid for X-linked loci than for autosomal loci and co-adaptation is promoted. In addition, co-adapted gene complexes which are located on the sex chromosomes may also acquire at least partial protection from decay through recombination because the heteromorphic nature of this pair of chromosomes in the heterogametic sex reduces crossingover (Ford, 1975). However, this mechanism would not be important in those groups in which recombination does not normally occur in the heterogametic sex, such as Drosophila (Gardner, 1972) and some Lepidoptera (Turner and Sheppard, 1975). The generality and full understanding of $\mathrm{X}$-linked inheritance of species-specific communication systems will depend, of course, on further study.

Acknowledgments.-The authors would like to thank Dr James D. McChesney, of the University of Mississippi, for technical assistance and for making available the resources needed to complete this work. The research was supported by the University of Kansas General Research Fund (Grant No. 3245-6038).

\section{REFERENCES}

AE, s. A. 1959. A study of hybrids in Colias (Lepidoptera, Pieridae). Evolution, 13, 64-88. ALEXANDER, R. D. 1962. Evolutionary change in cricket acoustical communication. Evolution, 16, 443-467.

AVERHOFF, W. W., AND RICHARDSON, R. H. 1976. Multiple pheromone system controlling mating in Drosophila melanogaster. Proc. Natl. Acad. Sci. U.S.A., 73, 591-593.

BARROWS, E. M., BELL, W. J., AND MICHENER, C. D. 1975. Individual odor differences and their social functions in insects. Proc. Natl. Acad. Sci. U.S.A., 72, 2824-2828.

BENTLEY, D. R. 1971. Genetic control of an insect neuronal network. Science, 174, 11391141.

ehrman, L. 1970. The mating advantage of rare males in Drosophila. Proc. Natl. Acad. Sci. U.S.A., 67, 345-348.

EwING, A. w. 1969. The genetic basis of sound production in Drosophila pseudoobscura and D. persimilis. Anim. Behav., 17, 555-560.

FORD, E. B. 1975. Ecological Genetics. Chapman and Hall, London.

Gardner, E. J. 1972. Principles of Genetics, 4th ed. John Wiley and Sons, N.Y.

GEROULD, J. H. 1943. Genetic and seasonal variations of orange wing-color in Colias butterflies. Proc. Amer. Phil. Soc., 86, 405-438.

GRANT, G. G., BRADY, U. E., AND BRAND, J. M. 1972. Male armyworm scent brush secretion. Identification and electroantennogram study of major components. Ann. Ent. Soc: Amer., 65, 1224-1227.

GRULA, J. W. 1978. The inheritance of traits maintaining ethological isolation between two species of Colias butterflies. Ph.D. Dissertation, University of Kansas.

hovanitz, w. 1944. Genetic data on the two races of Colias chrysotheme in North America and on a white form occurring in each. Genetics, 29, 1-29.

HOY, R. R., HAHN, J., AND PAUL, R. C. 1977. Hybrid cricket auditory behaviour: Evidence for genetic coupling in animal communication. Science, 195, 82-83.

LANIER, G. N. 1970. Pheromones: Abolition of specificity in hybrid bark beetles. Science, 169, 71-72.

LEONARD, J. E., AND EHRMAN, L. 1976. Recognition and sexual selection in Drosophila: Classification, quantification, and identification. Science, 193, 692-695. 
MAEKI, K. AND REMington, C. L. 1960. Studies of the chromosomes of North American Rhopalocera. 2. Hesperiidae, Megathymidae, and Pieridae. 7. Lep. Soc., 14, 37-57. o'donald, P. 1962. The theory of sexual selection. Heredity, 17, 541-552.

Robinson, R. 1971. Lepidoptera Genetics, Pergamon Press, N.Y.

ROELOFS, W. L., AND COMEAU, A. 1971. Sex pheromone perception: Electroantennogram responses of the red-banded leaf roller moth. F. Insect physiol., 17, 1969-1982.

RUTowsKI, R. 1977. Chemical communication in the courtship of the small sulfur butterfly Eurema lisa (Lepidoptera, Pieridae). F. Comp. Physiol., 115, 75-85.

SANDERs, c. J., DATERMAN, G. E., AND ENNIS, T. G. 1977. Sex pheromone responses of Choristoneura spp. and their hybrids (Lepidoptera: Tortrididae). Canad. Ent., 109, 1201-1220.

SHOREY, H. H., AND HALE, R. L. 1965. Mass-rearing of the larvae of nine noctuid species on a simple artificial medium. F. Econ. Ent., 58, 522-524.

SILBERGLIED, R. E., AND TAYLOR, O. R. 1973. Ultraviolet differences between the sulfur butterflies, Colias eurytheme and $C$. philodice, and a possible isolating mechanism. Nature, 241, 406-408.

SILBERGLIED, R. E., AND TAYLOR, O. R. 1978. Ultraviolet reflection and its behavioral role in the courtship of the sulfur butterflies, Colias eurytheme and C. philodice (Lepidoptera : Pieridae). Behav. Ecol. Sociobiol., 3, 203-242.

TAYLOR, o. R. 1972. Random vs. non-random mating in the sulfur butterflies, Colias eurytheme and $C$. philodice (Lepidoptera, Pieridae). Evolution, 26, 344-356.

TURNER, J. R. G., AND SHEPPARD, P. M. 1975. Absence of crossing-over in female butterflies (Heliconius). Heredity, 34, 265-269. 